\title{
Pathways to European Policy and Regulation in the Crypto-economy
}

\section{Abstract}

The EU has yet to develop definitive policies for the crypto-economy, and this article argues that policy development should follow a 'systemic' and not 'sectoral' approach. This is because the crypto-economy is not merely a financialised space and new productive activity is occurring that would benefit from more holistic policy development than regulation focused on securities and investments. This article proposes that the EU should develop policy for the crypto-economy based more broadly on innovation policy and perhaps feed into the Single Market project.

\section{Introduction}

The crypto-economy has grown in scale over the last couple of years, despite policy-makers' doubts that the essential characteristics ${ }^{1}$ of crypto-'currencies' and assets are substitutable ${ }^{2}$ with conventional ones (hence limiting their potential to become mainstream) and that they pose no threat to systemic stability in financial and real economies. ${ }^{3}$ Over USD\$570m have been raised by crypto-token sales in the three months Feb-April $2019^{4}$ and Europe enjoys a significant slice of the action in the crypto-economy. Statistics show that the UK is a popular jurisdiction for crypto-token sales alongside European neighbours France and the Netherlands. ${ }^{5}$ Malta ${ }^{6}$ hosts the globally popular crypto-exchange, Binance, ${ }^{7}$ not to mention that the world's oldest and most established cryptoexchange Coinbase ${ }^{8}$ serves a global customer base many of whom are based in Europe and the UK.

There is substantial EU-level discussion in relation to the crypto-economy ${ }^{9}$ and the technology that powers this economy, i.e. distributed ledger technology, ${ }^{10}$ but definitive regulatory policies are not yet offered. This article discusses the contesting forces that are shaping regulatory policy and argues that EU innovation policy provides an optimal basis for the fashioning of a regulatory policy that is likely to be more comprehensive and thoughtful in nature.

\footnotetext{
${ }^{1}$ There is extensive discussion that crypto-currencies are not currency as they do not really work as a store of value or unit of account, and that even if treated as 'assets', their price volatility greatly impairs their desirability, see for example Part V, BIS Annual Economic Report 2018, 'Cryptocurrencies- Looking Beyond the Hype' at https://www.bis.org/publ/arpdf/ar2018e5.pdf.

${ }^{2}$ In an earlier work, I look at substitutability as a key aspect of whether we should consider a novel trend as 'disruptive', see Iris H-Y Chiu, 'Fintech and Disruptive Business Models in Financial Products, Intermediation and Markets - Policy Implications for Financial Regulators' (2016) 21 Journal of Technology Law and Policy 168.

${ }^{3}$ Mark Carney, in a letter as Chair of the Financial Stability Board to the G20 Finance ministers and central bankers, 13 March 2018 at http://www.fsb.org/wp-content/uploads/P180318.pdf.

${ }^{4}$ https://www.coinschedule.com/stats.

5 'Crypto-token sales and market statistics', available at https://www.coinschedule.com/statsgeo/ALL?dates=Feb\%2001,\%202019\%20to\%20Apr\%2026,\%202019, providing details of popular jurisdictions and funds raised from token sales by time periods, geography etc.

${ }^{6}$ See 'Best Bitcoin and Cryptocurrency Exchange Reviews' at https://www.buybitcoinworldwide.com/exchanges/.

${ }^{7}$ https://www.binance.com/, according to coinmarketcap.com, over USD\$14bn is being traded on Binance as of 26 April 2019, see https://coinmarketcap.com/exchanges/binance/.

${ }^{8}$ https://www.coinbase.com/.

${ }^{9}$ Such as the EU Commission's Fintech action plan, EU Commission Communication, FinTech Action plan: For a More Competitive and Innovative European Financial Sector (2018) and European Banking Authority, Report with Advice for the European Commission on Crypto-assets (Jan 2019) at https://eba.europa.eu/documents/10180/2545547/EBA+Report+on+crypto+assets.pdf.

${ }^{10}$ Such as the establishment of the EU Blockchain Observatory and Forum, at https://www.eublockchainforum.eu/.
} 
Policy-makers may hesitate to nail down regulatory policy for the crypto-economy. Technological developments introduce new phenomena at a tremendous pace and there is concern that regulatory law can be inflexible in nature. ${ }^{11}$ There is a cautionary feel against the prematurity of legalising or regulating, especially at the EU level, as law is of a constitutive nature, being the means by which the economic order for the Single Market is built up, ${ }^{12}$ and is expressed in the instruments of the regulatory state, ${ }^{13}$ a key institution of governance in the EU. However, as Zumbansen puts it:

'[L]aw ought to be understood as a social system whose function should be seen in allowing communicative meaning to survive from the battlefield of contemporary conflict into tomorrow's search for stability, certainty (and memory). Law can fulfil this stabilising function-despite, or should we say because of its relative autonomy from the rule-production that is otherwise taking place in the parameters of economic exchange or political discourse.... At the same time, law competes with other narratives in making sense of the present regulatory challenges. ${ }^{14}$

We argue in this article that the main 'battle of contemporary conflict' in relation to fashioning EU regulatory policy for the crypto-economy lies in the contest between sectoral regulation i.e. the regulatory field for finance, and a more broad-based regulatory agenda that extends beyond financial sectoral regulation. We see 'sense-making' being developed in EU policy and academic discussions ${ }^{15}$ relating to the crypto-economy and distributed ledger technology, but such 'sensemaking' seems divided between two trajectories of policy development. One trajectory is to focus on similarities between crypto-fund-raising and assets, and conventional financial market equivalents. This results in a sectoral regulatory approach focused on finance. The other trajectory is to consider a new suite of economic regulatory policy for the novel features of the crypto-economy. The hesitation in adopting either trajectory is not helped by the lack of international convergence. ${ }^{16}$

In Section II, this article argues that the developments in the crypto-economy present two aspects for policy consideration. They are the 'productive' and 'financialised' aspects respectively. This Section will explain these inter-related aspects and argue that the current policy attention paid to the 'financialised' aspects is somewhat imbalanced. Due to the hype over crypto-token sales that are unregulated and the fears of investor scams, there may be an urgency to address reform in financial regulation. ${ }^{17}$ However, narrowly focusing policy-making on financial regulation may result in

\footnotetext{
${ }^{11}$ A critique against legalisation in the EU in Christian Joerges, 'Europe's Economic Constitution in Crisis' (2013) at https://papers.ssrn.com/sol3/papers.cfm?abstract_id=2179595.

12 Poul F Kjaer, 'European Crises of Legally-Constituted Public Power: From the "Law of Corporatism" To The

“Law Of Governance”' (2017) 23 European Law Journal 417.

${ }^{13}$ Giandomenico Majone, 'The Rise of the Regulatory State in Europe' (1994) 17 West European Politics 77, Daniel Muggë, 'From Pragmatism to Dogmatism: European Union Governance, Policy Paradigms and Financial Meltdown' (2011) 16 New Political Economy 185.

${ }^{14}$ Peer Zumbansen, 'Spaces and Places: A Systems Theory Approach to Regulatory Competition in European Company Law' (2006) 12 European Law Journal CHK.

${ }^{15}$ Michèle Finck, Blockchain Governance and Regulation in Europe (Cambridge: CUP 2018); Daniel Kraus, Thierry Obrist and Olivier Hari (eds), Blockchains, Smart Contracts, Decentralised Autonomous Organisations and the Law (Cheltenham: Edward Elgar 2019).

${ }^{16}$ There is no movement towards international convergence in regulatory policy for the crypto-economy, but the Financial Stability Board carries out a survey and monitoring function, see FSB, Crypto-asset Markets (2018) at http://www.fsb.org/wp-content/uploads/P101018.pdf.

17 UK's Crypto-assets Task Force Report (2018), at

https://assets.publishing.service.gov.uk/government/uploads/system/uploads/attachment data/file/752070/ cryptoassets taskforce final report final web.pdf, para 1.5. The report points out ongoing research and thinking about the crypto-economy and blockchain technology more holistically but seems to indicate that policy urgency is driven by the rise in crypto-assets coming to unregulated markets.
} 
disengaging the financialised aspects of the crypto-economy from its productive aspects. This would cause under-provision of policy development for the 'productive' aspects of the crypto-economy, which is argued to be sub-optimal. Section III analyses the drivers in the EU that may steer policymaking towards a narrow 'financial' focus as well as the 'balancing' drivers that compel consideration of a more holistic approach beyond financial regulation for the crypto-economy. The latter approach in our view is better able to provide for the 'productive' aspects of the cryptoeconomy and facilitate innovation-led benefits for economic growth and development. Section III thus deals with the 'battle of contemporary conflict' in relation to the different factors at work that influence EU policy-making for the crypto-economy. We argue that there are 'systemic' forces that influence policy-making at the EU level as well as 'sectoral' forces. By 'systemic', this article refers to forces influencing EU policy-making in relation to the Single Market or economic constitution, whether in terms of building up the Single Market or maintaining its integrity or confidence. This is differentiated in this article from the use of 'sectoral' which focuses more on the financial services industry, where policy-making adheres to specific aims and goals tied to remits of particular regulatory agencies.

In Section IV, this article argues that a 'systemic' approach to regulatory policy-making is more optimal. ${ }^{18}$ This approach can be drawn from EU innovation policy, which this Section discusses. Importantly, innovation policy encompasses both substantive and procedural aspects and brings in an institutionally-supported and holistic method for deliberations and dialogue. Section $V$ concludes.

\section{The Governance Needs of the Crypto-economy}

\section{A Snapshot of the Crypto-economy and Its Financialisation}

The beginnings of the crypto-economy lie in the 'technological revolution'19 in the advent of the blockchain (or distributed ledger technology). The bitcoin blockchain ${ }^{20}$ first allowed a new cadre of economic actors to be introduced (nodes), ${ }^{21}$ defined a new paradigm of production and wealth creation (mining), ${ }^{22}$ and created a unique environment for exchange and community without the need for centralised institutions of trust and enforcement. ${ }^{23}$ The bitcoin blockchain ushered in a new technology for economic interaction that is potentially disruptive, representing a step beyond the platform economy, ${ }^{24}$ which has brought about new business models and markets since the time of eBay in the late 1990s. The 'flattening of the world economy' ${ }^{25}$ has galvanised new economic actorhood, activity and creation of wealth. The blockchain takes this further by offering a

\footnotetext{
${ }^{18}$ The lens of innovation policy is explored in Section IV. It is also noted that a more 'holistic' agenda for regulatory thinking in the crypto-economy is urged by the European Banking Authority, see Report with Advice for the European Commission on Crypto-assets (Jan 2019) at https://eba.europa.eu/documents/10180/2545547/EBA+Report+on+crypto+assets.pdf.

${ }^{19}$ See Carlotta Perez, Technological Revolutions and Financial Capital: The Dynamics of Bubbles and Golden Ages (Cheltenham: Edward Elgar 2002).

${ }^{20}$ Satoshi Nakamoto, 'Bitcoin: A Peer to Peer Electronic Cash System' (2008) at https://bitcoin.org/bitcoin.pdf.

${ }^{21}$ I.e. anyone who wished to connect his/her computer to the blockchain.

22 New value can be created on the blockchain by performing maintenance tasks based on cryptographic validation, i.e. the performance of those tasks leads to reward in value that can be used on the blockchain.

${ }^{23}$ This is because the blockchain relies on a system of decentralised work of verification and validation that is aimed at being tamper-proof.

${ }^{24}$ Martin Kenney and John Zysman, 'The Rise of the Platform Economy' (2016) Issues in Science and

Technology 61 which sees digital platforms as offering new business models, at

https://www.nbp.pl/badania/seminaria/25x2016_2.pdf.

${ }^{25}$ Thomas L Friedman, The World is Flat (Farrar, Straus and Giroux 2005); Gillian Hadfield, Rules for a Flat World (Oxford: OUP 2016).
} 
disintermediated way of economic connection that is yet maintained by automation protocols that foster trust and reliability, ${ }^{26}$ challenging the notion that economic actorhood and activity need to be conventionally organised or ordered.

The development of the ethereum blockchain ${ }^{27}$ is the next significant and crucial step for the revolutionising potential of distributed ledger technology (DLT). The distributed ledger can now support a variety of economic activity more complex than the initially dominant activity of payment transfer, allowing for smart contracts ${ }^{28}$ to be coded and executed on the ledger to effect a range of economic activity, including future or conditional contractual performance. This development crucially underlies two recent trends. One is that the ethereum blockchain can be used by businesses to issue rights and privileges to their supporters, i.e. the 'initial coin offering' (ICO) movement, in return for development finance. ${ }^{29}$ Secondly, the ethereum blockchain can be used to improve efficiencies and reliability in disparate recording and management systems for data, processes or networks, in both commercial and non-commercial contexts. ${ }^{30}$ This article focuses on the firstmentioned development in relation to the building of a crypto-economy as an alternative economic space, as this space is where new issues for policy and regulation arise.

Much of the crypto-economy takes place in an unregulated space but it is observed that many jurisdictions are increasingly extending regulation, especially in relation to initial coin offerings. ${ }^{31}$ These offerings resemble regulated fund-raising such as public offers of securities and give rise to issues of investor protection and regulatory arbitrage. The ease with which developers of distributed ledger technology projects have secured funding ${ }^{32}$ and the high failure rate of projects ${ }^{33}$ have raised

\footnotetext{
${ }^{26}$ The distributed ledger is a concept whereby all nodes maintain the same copy of transactions and last-done status of the ledger, so that all records are immutable, indelible and cannot be arbitrarily adjusted. This is described as 'trustless trust' but see limitations discussed in Kevin Werbach, 'Trust, But Verify: Why the Blockchain Needs the Law' (2018) 33 Berkeley Tech. L.J. 489 (2018).

${ }^{27}$ See https://www.coindesk.com/information/who-created-ethereum.

${ }^{28}$ These are pieces of code or algorithms designed to execute certain commands if certain conditions are met, resulting in the execution or formation of legal obligations, hence 'smart contracts', see Nick Szabo, 'Smart Contracts: Building Blocks for Digital Markets', University of Amsterdam (1996),

http://www.fon.hum.uva.nl/rob/Courses/InformationInSpeech/CDROM/Literature/LOTwinterschool2006/szab o.best.vwh.net/smart_contracts_2.html, and layman's version at https://www.coindesk.com/information/ethereum-smart-contracts-work.

${ }^{29}$ There is a lot of literature mapping the universe of ICOs, see S Adhami et al, 'Why do Businesses Go Crypto? An Empirical Analysis of Initial Coin Offerings' (2018) 100 Journal of Economics and Business 64; Dirk Zetzsche et al,, 'The ICO Gold Rush: It's a Scam, it's a Bubble, it's a Super Challenge for Regulators' (2017) at http://ssrn.com/abstract=3072298.

${ }^{30}$ This was discussed in relation to a variety of areas such as clearing and settlement, ESMA, The Distributed Ledger Technology Applied to Securities Markets (Discussion Paper, June 2016); Andrea Pinna and Wiebe Ruttenberg, 'Distributed Ledger Technologies in Securities Post-Trading' (ECB Working Paper 2016); David S Evans, 'Economic Aspects of Bitcoin and Other Decentralized Public-Ledger Currency Platforms' (2014) at http://ssrn.com/abstract=2424516, on shareholder voting see Christoph van der Elst, 'Blockchain and Smart Contracting for the Shareholder Community' (2018) at

https://papers.ssrn.com/sol3/papers.cfm?abstract id=3219146. On management of networks such as supply chains, see Kari Kopela et al, 'Digital Supply Chain Transformation toward Blockchain Integration' (2017) at https://scholarspace.manoa.hawaii.edu/bitstream/10125/41666/paper0517.pdf. Also DLT can be used to create records in order to prevent tampering, such as in relation to food aid and distribution in Africa, see https://www.coindesk.com/un-food-program-to-expand-blockchain-testing-to-african-supply-chain.

${ }^{31}$ To be discussed below. This is the term initially used for crypto-token sales, but the terminology has moved on to distinguish between token sales and initial coin offerings, as the former may be private sales and not open to the public. The more generic description of token sales may also be intended to disengage association with initial public/securities offerings.

${ }^{32}$ See the statistics mentioned, above $\mathrm{n} 4$.
} 
concerns about the 'wild west' of this unregulated space. This development is discussed in greater detail in Section III as a significant trend that can influence EU policy thinking.

In order to fund distributed ledger technology-based development projects, developers typically offer 'tokens' in return for cryptocurrency such as bitcoin or ether from supporters of the project. These tokens are the native 'coin' in the ledger. ${ }^{34}$ What this means is that the 'coin', a standardised piece of code, embodies an entitlement to participate in the ledger as well as a unit of value for transfer. The native coins of the ledger power its economic operations in due course. A number of commentators have profiled the nature of 'tokens' ${ }^{35}$ which confer a variety of consideration in return for supporters' funds. For example, utility tokens confer on subscribers a right (in the future) to use or enjoy certain services developed by the ledger-based business. 'Fun' tokens may confer a benefit to the community at large. Investment tokens confer on subscribers a right to participate in a form of investment and are functionally closest to regulated securities or investment funds. Currency tokens confer on subscribers a right to use for payment in a more interoperable manner than utility tokens. Examples include bitcoin, ether or other coins of more significant circulation and volume of trading. ${ }^{36}$

$\mathrm{Kaal}^{137}$ documents that the majority of initial coin offerings are for 'utility tokens'. It has been argued that the need for regulatory arbitrage is the key reason for this form of fund-raising, i.e. that developers structure the fund-raising as pre-sales of goods or services in order to avoid being classified as offering securities without complying with the securities regulation. ${ }^{38}$ However, the sales of 'coins' or 'tokens' can also be regarded as intrinsic to the DLT-based business model as tokens are an integrated representation of productive participation and economic value on the ledger. ${ }^{39}$ Pre-selling the native coin/token of the ledger ensures a critical mass of participation (or network effects) for the DLT-based business model when it becomes live. However, as the mechanics of fund-raising mimick the market for conventional securities fund-raising, policy-makers remain divided as to whether token sales should be subject to securities regulation.

The fund-raising mechanics include developers' production of a white paper, which is a form of voluntary disclosure, mimicking the disclosure document for securities fund-raising. ${ }^{40} \mathrm{~A}$ variety of information services have also arisen in this unregulated sphere to bridge developers and supporters. For example, coindesk.com carries announcements and opinions on upcoming offerings, and services such as Smith and Crown maintain upcoming ICO lists. Services that 'vet' or 'rate' upcoming ICOs have arisen to fulfil an information mediation role. For example, ICOBench provides ratings (a numerical figure out of 5 ) for the ICO profile, team, vision and product. Platforms have arisen to host the primary market in ICOs, and they reputationally back an ICO in order to mediate

\footnotetext{
${ }^{33}$ Ana Alexandre, 'New Study Says 80 Percent of ICOs Conducted in 2017 Were Scams' (2018) at https://cointelegraph.com/news/new-study-says-80-percent-of-icos-conducted-in-2017-were-scams.

${ }^{34}$ Bastien Buchwalter, 'Decrypting Cryptoassets: A Classication And Its Implications' (2019) at https://ssrn.com/abstract=3271641.

35 Philip Hacker and Chris Thomale, 'Crypto-Securities Regulation: ICOs, Token Sales and Cryptocurrencies under EU Financial Law' (2018) ECFR 645; Zetzsche et al (2017) at http://ssrn.com/abstract=3072298; Jonathan Rohr and Aaron Wright, 'Blockchain-Based Token Sales, Initial Coin Offerings, and the Democratization of Public Capital Markets' (2017) at http://ssrn.com/abstract=3048104 amongst others.

${ }^{36}$ David Lee (ed), The Handbook of Digital Currencies (Elseiver 2015).

${ }^{37}$ Wulf A Kaal, 'Crypto-Economics- The Top 100 Token Models Compared' (2018) at https://ssrn.com/abstract=3249860.

38 Usha Rodrigues, 'Semi-Public Offerings? Pushing the Boundaries of Securities Law' (2018) at https://ssrn.com/abstract=3242205.

${ }^{39}$ Buchwalter (2019) at https://ssrn.com/abstract=3271641.

40 Zetzsche et al (2017).
} 
information asymmetry (eg CoinList, ICO Engine, BlockEx). It is noteworthy that many platforms acting as primary markets and rating services are new businesses, sometimes offering ICOs themselves! This landscape arguably resembles the eco-system surrounding companies' 'initial public offers', from book-building, information intermediaries and primary markets, missing only the key intermediary of an investment bank.

Supporters are attracted to such pre-sales because of the 'liquefication' of tokens. The tokens conferred on purchasers at pre-sales can usually be immediately traded away, on one of many digital asset exchanges that have arisen all over the world, in exchange for more popular cryptocurrencies such as bitcoin or ether, which can then be exchanged for fiat currencies. The 'liquefication' of tokens fundamentally allows them to become financialised, turning tokens into financial instruments, which the Bank of England now defines as 'generally held as investments by people who expect their value to rise. ${ }^{41}$ Crucially the liquefication of tokens appeals to a wide range of potential purchasers of tokens who are not committed to the project and can be speculators. In essence the crypto-economy has been transformed into a crypto investment economy by virtue of token financialisation. ${ }^{42}$ The value generated by the crypto-economy is very much seen now in terms of the value raised by initial coin offerings ${ }^{43}$ and there is far more hype surrounding the launch of an offering than the launch of the project that is to be developed after the offering.

As will be discussed in Section III, immediate regulatory discussions revolve around whether securities or investment regulation should be extended to tokens, especially utility tokens. This approach is 'coherentist' ${ }^{44}$ as it seeks to fit innovations within existing legal frameworks. ${ }^{45}$ Existing legal frameworks are not always technology-neutral and timeless, and financial regulation exhibits a high level of anchoring in precisely-described financial technology, such as in relation to defining securities, ${ }^{46}$ investment funds, ${ }^{47}$ and other financial instruments. This makes it difficult to establish unequivocal fits between token financing and existing regulatory regimes. Significant amounts of legal effort can be spent on arguments regarding the interpretation of regulatory scope and boundaries. This work does not revisit the issues of where the 'fits' lie as there is substantial existing academic writing in this area. ${ }^{48}$ Many regulators worldwide engage with this approach but we argue that one should take a step back from the contests in legal characterisation of fund-raising and look at the crypto-economy as an alternative economic space as a whole. This allows us to understand the crypto-economy in relation to two aspects: its productive and financialised aspects.

\section{The Productive Aspects of the Crypto- economy}

\footnotetext{
${ }^{41}$ https://www.bankofengland.co.uk/knowledgebank/what-are-cryptocurrencies.

${ }^{42}$ Gerald A Epstein ed, Financialization and the World Economy (Cheltenham: Edward Elgar, 2005) at 3 defines this term to mean the increasing role of financial motives, financial markets, financial actors and financial institutions in the operation of the economies.

${ }^{43}$ Almost a 1,000 ICOs were recorded between March 2018 and Jan 2019, raising over USD\$18 bn see https://www.coinschedule.com/stats.

${ }^{44}$ Roger Brownsword, 'Regulatory Fitness: Fintech, Funny Money, and Smart Contracts' (2019) 20 European Business Organisations Law Review 5.

${ }^{45}$ Also taken in the US, and the UK FCA has clarified the regulatory perimeter, defending but not extending its regulatory scope, see FCA, Guidance on Cryptoassets: Policy Statement (July 2019) at https://www.fca.org.uk/publication/policy/ps19-22.pdf.

${ }^{46}$ Such as securities defined for the purposes of the Prospectus Regulation 2017 is highly tied to corporate forms and a certain understanding of market tradeability or liquidity.

${ }^{47}$ For example UCITs as retail investment funds regulated in the EU UCITs Directive 2009 defines such funds in relation to investing in transferable securities, so such a retail investment product is tied to 'securities' which as noted above, are defined by their technologies of origination and liquidity.

${ }^{48}$ Hacker and Thomale (2018); Iris M Barsan, 'Legal Challenges of Initial Coin Offerings (ICO)' (2017) 3 RTDF 54.
} 
At its truly disruptive level, a DLT-based business model can be distinguished from accepted corporate or partnership forms, and its financing needs explain the optimality of token financing. The productive aspects of the DLT-based business model have implications for new economic productivities and mobilisation. In this manner, regulatory design for both the productive and financialised aspects can be fashioned in a holistic manner, preventing the focus on the latter from undermining the former.

DLT-based business models provide peer-to-peer platforms for direct transactions in new forms of commodification, ${ }^{49}$ creating new markets for novel goods or services. For example, DLT-based platforms can facilitate peer-to-peer energy trading, disrupting and challenging existing oligopolistic markets in energy..$^{50}$ WePower's business model facilitates peer-to-peer trading of green energy that is individually produced by harnessing solar power at home. ${ }^{51}$ lungo provides a disintermediated platform to link up individual wifi services to become a network of global wireless internet; ${ }^{52}$ Golem is a business model that allows access to individual computers' idle power for a fee,,$^{53}$ and brings together a network of computers willing to share their 'excess capacities'. There is also potential in Cappasity's model of creating a distributed marketplace for online creators of games and virtual reality experiences, ${ }^{54}$ and Madana's model ${ }^{55}$ of a distributed marketplace for data that could attempt at disrupting the economic power that big data giants such as Google and Amazon have amassed. ${ }^{56}$

DLT-based business models, like platform economic models in the sharing economy, ${ }^{57}$ create communities of users who engage in different sides of the market, encouraging new economic mobility that is unshackled from the frames of current economic or business models, such as shareholder primacy in corporations, ${ }^{58}$ or the neoliberal disembeddedness of markets from society. ${ }^{59}$

\footnotetext{
${ }^{49}$ The trend of new commodification that has been made possible by digitalisation is discussed in Miriam Cherry, 'Cyber Commodification' (2013) 72 Maryland Law Review 381.

${ }^{50}$ Competition in the energy sector, such as in the UK has long been a challenging issue, see for example, Competition in the UK's Electricity Market (2016) at https://assets.publishing.service.gov.uk/government/uploads/system/uploads/attachment data/file/556310/ Electricity competition.pdf showing that entrenched players (the Big 6 companies) continue to take over $80 \%$ of market share although new and smaller players are challenging such a trend gradually.

${ }^{51}$ https://wepower.network/. Indeed peer-to-peer energy trading is growing in a number of Continental countries, e.g. see Thomas Morstyn et al, 'Using Peer-To-Peer Energy-Trading Platforms to Incentivize Prosumers to Form Federated Power Plants' (2018) 3 Nature Energy; Jodie Giles, 'Giles, Jodie. "Peer to Peer Trading and Microgrids - the next Big Thing?”. Regen, 21 February 2018, https://www.regen.co.uk/peer-topeer-trading-and-microgrids-the-next-big-thing/; David Shipworth, "Peer-to-Peer Energy Trading Using Blockchains". DSM Spotlight- The Newsletter of the International Energy Agency Demand-Side Management Programme, No. 67, December 2017, pp. 5-9, http://www.ieadsm.org/wp/files/IEA-DSM-Spotlight-Issue67December20171.pdf.

52 https://iungo.network/.

53 See https://golem.network/.

${ }^{54}$ https://cappasity.com/.

55 https://www.madana.io/.

${ }^{56}$ Jonathan M Barnett, 'The Costs of Free: Commodification, Bundling and Concentration' (2017) at https://papers.ssrn.com/sol3/papers.cfm?abstract_id=2916859.

${ }^{57}$ Arun Sundarajan, The Sharing Economy (Mass: MIT Press 2016); Alyse Killeen, 'The Confluence of Bitcoin and the Global Sharing Economy' in David Lee (ed), The Handbook of Digital Currencies (Elseiver 2015) at ch24.

${ }^{58}$ See much more extensive discussion in A Keay, 'Shareholder Primacy in Corporate Law : Can it Survive? Should it Survive?' (2010) 7 European Company and Finanacial Law Review 369. At the global level, shareholder primacy is argued to be the dominant model of the corporate economy, $\mathrm{H}$ Hansmann and $\mathrm{R}$ Kraakman, 'The End of History for Corporate Law' (2000) 89 Georgetown Law Journal 439.
} 
At its best, the crypto-economy model ${ }^{60}$ has the potential to usher in a new age of an economic society.

The productive aspects of the new crypto-economy present certain novel features. Genuine DLTbased business models ${ }^{61}$ feature a high level of decentralisation but also a high degree of standardisation. These models require mass participation to build up alternative networks distinguished from institutional ones, such as lungo's global wireless internet, and can be highly 'democratised' and open as entry or exit is by purchase or sale of the ledger's token. At the same time, participation is highly marketised, and the only institutions of 'order' are smart contract protocols that standardise transactions and transfers of value. It should not be assumed that smart contractual governance is sufficient and that 'code is law'. Various issues can arise that could affect the productive operations in the crypto-economy.

Smart contracts are programmed to execute pre-defined transactions under certain conditions on the ledger and the high levels of standardisation may be inflexible and also unable to deal with 'offchain' legs of the transaction. A smart contract for the purchase and sale of peer-produced energy units may be able to execute the transaction as well as effect and record transfer of value. However, the delivery of the energy units is 'off-chain', i.e. facilitated by other infrastructure such as the national grid, as the DLT-based platform is not a complete infrastructure for certain types of transactions. It is queried whether there is a need for governance rules in relation to on-chain and off-chain coordination, ${ }^{62}$ such as dispute resolution systems unique to DLT-based platforms ${ }^{63}$ What if a contractual arrangement ought to be vitiated, for example because it was made with a minor participant or a participant under duress? How would mistakes and errors be dealt with ex post? ${ }^{64}$

If a DLT-based platform is for the purposes of transacting purely on-chain crypto-goods such as crypto-kitties, ${ }^{65}$ the smart contracts may be able to deal with the transaction from end to end. However, this gives rise to the question whether there are indeed central entities maintaining order and integrity on-chain and if so, what organisational form is being maintained by the ledger, and what governance roles and responsibilities central entities should assume. If ledgers are, like the bitcoin blockchain, a permissionless blockchain that institutes a system of trust despite the lack of coordination, there is a need to consider if developers of the platform, code writers and 'miners or minters' who co-create coins/tokens for the system, and therefore, wealth, are particular loci of

\footnotetext{
59 John Ikerd, 'Sustainable Capitalism: A Matter of Ethics and Morality' (2008) 3 Problems of Sustainable Development 13; Grietje Baars, “'Reform or Revolution”? Polanyian Versus Marxian Perspectives on the Regulation of The Economic' (2011) 62 NILQ 415; L Boldeman, The Cult of the Market (ANU Press, 2007), generally.

${ }^{60}$ See vision in Primavera De Filippi, 'Translating Commons-Based Peer Production Values into Metrics: Toward Commons-Based Cryptocurrencies' in The Handbook of Digital Currencies (Elseiver 2015) at ch23.

${ }^{61}$ Because of the successes of many early ICOs, many business proposals that are framed as ICOs chase after the hype but are not necessarily unique to being powered by distributed ledger technology. See 'A Failed ICO is Trying to Flog Itself on Ebay' (Financial Times, 25 March 2019) at https://www.google.com/url?sa=t\&rct=j\&q=\&esrc=s\&source=web\&cd=4\&cad=rja\&uact=8\&ved=2ahUKEwjVo 8vOzKLhAhXTWhUIHfjKCIOQFjADegQIBBAB\&url=https\%3A\%2F\%2Fftalphaville.ft.com\%2F2019\%2F03\%2F25\%2 F1553498702000\%2FA-failed-ICO-is-trying-to-flog-itself-on-eBay-\%2F\&usg=AOvVaw2KgfoabkWpbkTIXrD4f3gs. 62 Finck (2018) above.

${ }^{63}$ Florian Möslein, 'Legal Boundaries of Blockchain Technologies: Smart Contracts as Self-Help?' in A De Franceschi, R. Schulze, M. Graziadei, O. Pollicino, F. Riente, S. Sica and P. Sirena (eds.), Digital Revolution - New Challenges for Law (Cambridge: Intersentia 2019).

${ }^{64}$ Sarah Green, 'Smart Contracts : Interpretation and Rectification' (2018) LMCLQ 234.

${ }^{65}$ https://www.cryptokitties.co.
} 
power in DLT-based systems, ${ }^{66}$ and what their responsibilities should be. ${ }^{67}$ Further the marketised model can facilitate concentrations in token holdings and it is queried if this phenomenon and the powers held by token block-holders should be governed.

Commentators have also discussed a number of pertinent legal and regulatory issues such as the legal risks of automation ${ }^{68}$ and data protection and security.$^{69}$ There is a wealth of issues that has surfaced, and there is a need to engage in the larger dialogue in relation to whether regulatory policy is needed in order to facilitate and govern the productive aspects in a holistic manner, such as in relation to organisation of productive activity, ${ }^{70}$ allocation of responsibilities, decision-making and accountability ${ }^{71}$ and distribution policies. ${ }^{72}$ These issues complement regulatory thinking in relation to the financialised aspects of the crypto-economy.

\section{EU Policy on the Crypto-economy- No Systemic Approach Yet in Sight?}

EU policy on the crypto-economy is in development and can be gleaned from the EU Commission's Action Plan on Fintech, ${ }^{73}$ and policy indications from the European financial regulatory agencies. The European Banking Authority (EBA) has published a report on Cryptoassets ${ }^{74}$ and the European Securities and Markets Authority's (ESMA) and European Central Bank's (ECB) have issued earlier papers on blockchain. ${ }^{75}$ Further, the EU's Blockchain Observatory and Forum has engaged in knowledge production and dialogue. ${ }^{76}$

At the same time, national policy-making is underway in other jurisdictions. ${ }^{77}$ The UK $^{78}$ and Luxembourg ${ }^{79}$ instituted regulatory sandboxes where innovations can be tested in an environment that disapplies regulation to an extent in order for both firms and regulators to learn about the needs of governance. These arenas are likely to interact with EU policy-making ${ }^{80}$ and EU policymaking is unlikely to be an insular process. However, EU policy-making must still be derived from its

\footnotetext{
${ }^{66}$ Queried in EU Blockchain Observatory and Forum Workshop Report -Legal Recognition of Blockchains \& Smart Contracts (2018).

${ }^{67}$ Queried in Angela Walch, 'Deconstructing 'Decentralization': Exploring the Core Claim of Crypto Systems' (2019) at https://ssrn.com/abstract=3326244; Matthias Tarasiewicza, Andrew Newman, 'Cryptocurrencies as Distributed Community Experiments' in The Handbook of Digital Currencies (Elseiver 2015) at ch10. See also Karen Yeung, 'Regulation by Blockchain: The Emerging Battle for Supremacy between the Code of Law and Code as Law' (2019) Modern L. Rev (forthcoming); Philipp Hacker, 'Corporate Governance for Complex Cryptocurrencies? A Framework for Stability and Decision Making in Blockchain-Based Organizations' in P Hacker et al eds, Regulating Blockchain: Techno-Social and Legal Challenges (Oxford: OUP 2019) at 16. ${ }^{68}$ Primavera de Fillippi and Aaron Wright, Blockchain and the Law (Mass: Harvard University Press 2018) at ch9.

${ }^{69}$ Finck (2018).

${ }^{70}$ Queried in EU Blockchain Observatory and Forum Workshop Report (2018).

${ }^{71}$ See $n 67$.

72 Relating to how creation of wealth should be distributed.

${ }^{73}$ EU Commission Communication, FinTech Action Plan (2018).

${ }^{74}$ EBA, Report with Advice to the European Commission on Cryptoassets (Dec 2018) at https://eba.europa.eu/documents/10180/2545547/EBA+Report+on+crypto+assets.pdf.

${ }^{75}$ ESMA, The Distributed Ledger Technology Applied to Securities Markets (Discussion Paper, June 2016); Pinna and Ruttenberg (ECB Working Paper 2016).

76 Ibid.

77 See discussion in text below.

78 The UK's regulatory sandbox regime is discussed in Iris H-Y Chiu, 'A Rational Regulatory Strategy for Governing Financial Innovation' (2017) 8 European Journal of Risk Regulation 743.

79 Dirk A Zetzsche, Ross P Buckley, Douglas W Arner and Janos Barberis, 'Regulating a Revolution: From Regulatory Sandboxes to Smart Regulation' (2017) 23 Fordham Journal of Corporate and Financial Law 31.

${ }^{80}$ Delemarle and Larédo (2014).
} 
governance systems, whether these are multi-level, multi-actored or framed in a variety of possible governance instruments from hard to soft law. ${ }^{81}$

The article turns to how the EU's own governance systems would make sense of the range of forces that shape its policy-making. In this light, this article argues that sense-making within the EU's governance systems is in a potential 'battle of contemporary conflict' between two trajectories. One is a sectorally-defined trajectory where sense-making converges on the need to generate EU level policy and law in the area of financial regulation. The second is a systemically-driven trajectory that interprets the potential transformations by the crypto-economy more broadly as impacting general business, commerce, social relations and economic structures. Policy-making shaped by such perspectives would include but not be dominated by financial regulation initiatives.

\section{Sectorally-defined Path for EU Policy and Regulation of the Crypto-economy}

The sectorally-defined trajectory for EU policy-making is an attractive one based on the following driving forces. First, many national regulators elsewhere focus on the financialised aspects of the crypto-economy and can influence each other with similar or competitive regulatory approaches. Further, the introduction of Libra by Facebook ${ }^{82}$ may galvanise international response in financial regulation. Second, the development of financial sector regulatory agencies at the EU level has been a culminating moment of pan-European governance and there are movements towards increasing centralisation of policy-making at these agencies. This would be an institutionally-based rationale for relying on the financial sector regulatory agencies to derive relevant policy-making for the cryptoeconomy. However we also see push-back from the financial sector regulatory agencies in preference for a more holistic approach.

\section{a. Responses from Financial Regulators Worldwide}

Many jurisdictions have chosen to frame crypto-economy issues in relation to securities and investments. Some are concerned about regulatory arbitrage and institutional challenges while others embrace new opportunities and engage in regulatory competition ${ }^{83}$ to attract the cryptoeconomy. The variety of approaches taken shows little international convergence except in anti- tax avoidance and anti-money laundering, areas that have already achieved high levels of international convergence. ${ }^{84}$

A few popular jurisdictions for crypto fund-raising have taken the approach of clarifying the financial/securities regulatory perimeter but in a proportionate manner so as not to discourage the budding activities. These jurisdictions engage in a subtle form of regulatory competition. In 2018, Switzerland clarifies that utility tokens are not subject to securities law, and indirectly permits them

\footnotetext{
${ }^{81}$ Discussed in Ingeborg Tömmel, 'Modes of Governance and the Institutional Structures in the EU' in Ingeborg Tömmel and Amy Verdun (eds), Innovative Governance in the European Union (Colorado: Lynne Reiner 2009) at ch2; Alexander Caviedes and Willem Mass (eds), Sixty-five Years of European Governance (2016) 12 Journal of Contemporary European Research; David M Trubek and Louise G Trubek, 'New Governance \& Legal Regulation: Complementarity, Rivalry, and Transformation' (2006) 13 Columbia Journal of European Law 2. 82 'Libra: Facebook's Digital Currency' (Financial Times, 31 July 2019) at https://www.ft.com/content/0c5c4012-9100-11e9-b7ea-60e35ef678d2.

${ }^{83}$ As there is great mobility in the crypto-economy, regulatory competition can matter. See for a theoretical discussion, ch1, William Bratton, Joseph McCahery, Sol Piccioto and Colin Scott (eds), International Regulatory Competition and Coordination: Perspectives on Economic Regulation in Europe and the United States (Oxford Clarendon 1997) on how the mobility of incorporating entities matters for real regulatory competition. ${ }^{84}$ Rosario Girasa's Regulation of Cryptocurrencies and Blockchain Technologies: National and International Perspectives (Palgrave 2018) or books on bitcoin, such as Pedra Franco's Understandng Bitcoin (John Wiley \& Sons 2014).
} 
to be offered as being outside of the regulatory perimeter, via the process of seeking a 'no-action' letter from FINMA. ${ }^{85}$ Only offers of securities tokens are to be in compliance with securities regulation. Singapore takes a similar position, as it clarifies that only securities tokens are caught within its regulatory perimeter, ${ }^{86}$ and payment tokens must comply with existing commercial and regulatory laws, such as anti-money laundering laws. In 2019, the UK, a popular jurisdiction for cryptoasset offerings, has also taken a similar position to clarify its existing regulatory perimeter as not including utility and currency tokens.$^{87}$ In this manner, the clarification of the existing regulatory perimeter serves two odd purposes. One is that there appears to be an over-confidence in the adequacy of existing regulatory frameworks and that reform is not regarded as unnecessary. This is despite the acknowledgement that utility tokens are not likely to fall within existing regulatory frameworks for securities or payment instruments. Second, it can be argued this approach is intended to be narrow so that implicit permission is given to leave utility tokens to be selfregulatory. Although no formal 'exemption' regimes are articulated in Switzerland, Singapore or the UK, 'implicit permission' can be derived from the authorities' clear delineation of the regulatory perimeter and its inapplicability. Perhaps such a position can achieve a balance between the desire to embrace innovation and prevent existing regulation from unduly stifling such innovation, and providing an appearance of the strength of existing regulation and law. These approaches crucially do not expand the existing regulatory perimeter, except where anti-money laundering and tax laws are concerned. Although such approaches do not necessarily deter innovation, they also provide no policy or regulatory leadership.

The US, on the other hand features a mixture of state-based and federal approaches to the cryptoeconomy reflecting the dilemmas in taking regulatory leadership and serving a coherentist approach. Where tokens serve payment-like functions, there are signs of appetite in the US for introducing whole new enabling regulatory regimes to cater for new 'virtual currency' or money-service businesses. However these endeavours run against the more conservative approaches of the Securities Exchange Commission (SEC) and the Commodity Futures Trading Commission (CFTC) which focus more on clamping down on fraud and regulatory arbitrage.

Regulatory policy in the US is very much crafted along the lines of established sectoral delineations, with the regulatory regimes for money service businesses possibly applicable to cryptocurrency, the regulatory regime for securities offers possibly applicable to coin/token issuances and the regulatory regime for commodities, futures and derivatives trading possibly applicable to trading in these instruments. There are policy indications towards welcoming the crypto-economy, such as the Uniform Law Commission's introduction of a piece of uniform legislation ${ }^{88}$ that can provide states

\footnotetext{
85 'How FINMA's ICO Guidelines impact future ICOs in Switzerland' (KPMG, 26 Feb 2018) at https:/home.kpmg/ch/en/home/insights/2018/03/how-finmas-ico-guidelines-impact-future-icos-inswitzerland.html. Also see Dragan Zelic and Nenad Baros, 'Cryptocurrency: General Challenges of Legal Regulation and the Swiss Model of Regulation' paper presented at 33rd International Scientific Conference on Economic and Social Development - "Managerial Issues in Modern Business" -Warsaw, 26-27 September 2018.

${ }^{86}$ Monetary Authority of Singapore, 'A Guide to Digital Token Offerings' (13 Dec 2018) at http://www.mas.gov.sg/ /media/MAS/Regulations\%20and\%20Financial\%20Stability/Regulations\%20Guidanc e\%20and\%20Licensing/Securities\%20Futures\%20and\%20Fund\%20Management/Regulations\%20Guidance\%20 and\%20Licensing/Guidelines/A\%20Guide\%20to\%20Digital\%20Token\%200fferings\%20last\%20updated\%20on \%2030\%20Nov\%202018.pdf.

87 FCA, Guidance on Cryptoassets: Policy Statement (July 2019) at https://www.fca.org.uk/publication/policy/ps19-22.pdf.

${ }^{88}$ Regulation of Virtual Currency Business Act, at https://www.uniformlaws.org/committees/communityhome?CommunityKey=e104aaa8-c10f-45a7-a34a-0423c2106778.
} 
with a ready-made template to permit the setting up and due oversight of virtual currency businesses. In this manner, cryptocurrency businesses can be legitimised and enter the fray of competition for payment services. However, the Uniform legislation has not yet been passed in any state, and New York's existing Bitlicence regulations have been criticised to be unduly onerous. ${ }^{89}$

On the other hand, although the Uniform Act is drafted widely to be able to include all types of tokens, it excludes anything within the remit of the SEC and CFTC. Both the SEC ${ }^{90}$ and CFTC $^{91}$ have signalled tougher stances against regulatory arbitrage and the need to secure investor protection and market integrity.

The SEC's investigative report into the initial coin offering made by the DAO (Decentralised Autonomous Organisation) in $2017^{92}$ first extended securities regulation to token offerings based on the Howey test. The test characterises as a security any investment contract that satisfies the characteristics of being a profit-seeking business venture as a common enterprise. As the DAO issued tokens to participants to contribute to a 'common enterprise', and participants reasonably expected to earn profits through the DAO's principal objective, which was to fund other projects for a profitable return, the DAO's token offer met the requirements of the Howey test. However, the SEC has refused to say that tokens structured as 'utility' tokens are never securities, and it would be interpreted on a case-by-case basis if such tokens meet the Howey requirements. Indeed the SEC has intervened to halt and order refunds by Munchee, whose tokens relating to a food reviews ledger were unregistered, and imposed civil penalties on AirFox and Paragon. ${ }^{93}$

The CFTC's remit extends to trading in various derivative contracts specified in legislation. The Commodities Exchange Act administered by the CFTC also requires registration of trading operators and empowers the CFTC to exercise enforcement authority over fraudulent or manipulative activity on markets. ${ }^{94}$ Although the CFTC's 'Advisory' does not clarify what tokens are likely to be treated as 'commodities', ${ }^{95}$ a number of enforcement decisions potentially have wide import. For example in the CFTC's enforcement against My Big Coin Pay Inc, ${ }^{96}$ which is a token designed to be a cryptocurrency purportedly backed by gold, the decision can be interpreted narrowly or more

\footnotetext{
89 The Uniform Act potentially covers all forms of tokens, as well-circulated tokens such as bitcoin and ether are arguably as much a 'medium of exchange' or 'unit of account' as the native coin of a distributed ledger business that has made an ICO. The width of interpretation of both 'virtual currency' and 'virtual currency business' could cover ICOs themselves, as well as intermediaries that facilitate transfer, trading or custody of tokens. However, this width of interpretation can only sustain if tokens are definitively not securities or commodities.

${ }^{90}$ The SEC's approach is focused on making 'coherentist' interpretations of token offerings in relation to the definition of 'security', see above, Clayton's response to Ted Budd, at https://coincenter.org/files/201903/clayton-token-response.pdf, SEC, 'Statement on Digital Asset Securities Issuance and Trading' (16 Nov 2018) at https://www.sec.gov/news/public-statement/digital-asset-securites-issuuance-and-trading.

${ }^{91}$ The CFTC is also focused on interpreting the nature of crypto activities to determine if they fall within its jurisdictional scope, see CFTC, 'CFTC Staff Issues Advisory for Virtual Currency Products' (21 May 2018) at https://www.cftc.gov/PressRoom/PressReleases/7731-18.

92 SEC, Report of Investigation Pursuant to Section 21(a) of the Securities Exchange Act of 1934: The DAO (25 July 2017) at https://www.sec.gov/litigation/investreport/34-81207.pdf.

93 'Company Halts ICO After SEC Raises Registration Concerns' (11 Dec 2017) at https://www.sec.gov/news/press-release/2017-227; 'Two ICO Issuers Settle SEC Registration Charges, Agree to Register Tokens as Securities' (16 Nov 2018) at https://www.sec.gov/news/press-release/2018-264.

94 US Commodity Exchange Act 7 U.S.C. § 2a(1)(A)- (C).

${ }^{95}$ CFTC, 'Customer Advisory: Use Caution When Buying Digital Coins or Tokens' (July 2018) at https://www.cftc.gov/sites/default/files/2018-07/customeradvisory_tokens0718.pdf.

${ }^{96}$ CFTC v My Big Coin Pay Inc (26 Sep 2018) at https://www.cftc.gov/sites/default/files/2018-

10/enfmybigcoinpayincmemorandum092618.pdf.
} 
broadly. A narrow interpretation would be confined to the CFTC's enforcement against fraudulent schemes, as My Big Coin was issued to fund the founder's lavish lifestyle and not for project development. Such enforcement may signal that non-fraudulent token offers may not attract enforcement. However, the basis for enforcement against fraudulent schemes is that a 'commodity' is involved and the characterisation of My Big Coin as a commodity ${ }^{97}$ would potentially implicate most currency tokens of a similar nature. Further, as utility tokens are presales and would likely involve future delivery beyond the spot market exemption of 28 days, they could also fall within the definition of commodity futures..$^{98}$ The CFTC's enforcement against Bitfinex, ${ }^{99}$ a crypto trading platform that allows leveraged trading and future delivery beyond 28 days, and Coinflip, ${ }^{100}$ a crypto trading platform in swaps and options, seem to indicate that enforcement is based on the 'futures' aspects of trading.

As the US battles between signs of regulatory leadership for cryptocurrencies and path-dependency in the SEC's and CFTC's approaches, some jurisdictions have taken the approach of holding out as attractive and forward-looking regimes for the relocation of crypto-economic activities and investments. However, these regulatory pioneers have not ventured beyond financial regulation.

Thailand offers an authorisation regime ${ }^{101}$ for token offerings whether they are designed to function as crypto-currency (i.e. medium of exchange), utility tokens (i.e. conferring rights in respect of goods or services) or securities tokens (conferring rights in respect of participation in investment), as well as a regime for authorising token offering portals (i.e. the platforms used for conducting token offers), digital asset exchanges, brokers and dealers. Such authorisation is based on incorporation in Thailand. This approach presumes that the productive aspects of the crypto-economy are best accommodated within a jurisdiction's corporate law. This assumption needs to be questioned as the unique decentralised and standardised aspects of the DLT-based business model may require new thinking in organisational laws and governance. France ${ }^{102}$ offers an optional 'visa regime' for token issuers subject to a skeletal framework of rules such as disclosure, anti-money laundering and asset custodial duties, in order to exchange for being registered in France (onshoring) and able to engage in general solicitation. Again, this approach is sectorally-focused and presumes that DLT-based business models should best be incorporated.

\footnotetext{
${ }^{97}$ See decision above, where Justice Zabel refers to the definition of 'commodity' in the Commodity Exchange Act in order to determine the nature of My Big Coin and found in favour of the CFTC's argument that My Big Coin is a commodity.

${ }^{98}$ Commentators have noted that over the years, although the CFTC's jurisdiction has broadened over all sorts of commodities, there is also a rise in the liberation of trading in their derivatives. Hence inclusion within the scope of 'commodity' is not the same as achieving a prohibitive effect, see Alexandra G Balmer, Regulating Financial Derivatives (Cheltenham: Edward Elgar 2018) at ch8; Chris Muellerleile, 'Speculative Boundaries: Chicago and the Regulatory History of US Financial Derivative Markets' (2015) 47 Environment and Planning 1805.

99 'CFTC Orders Bitcoin Exchange Bitfinex to Pay $\$ 75,000$ for Offering Illegal Off-Exchange Financed Retail Commodity Transactions and Failing to Register as a Futures Commission Merchant' (2 June 2016) at https://www.cftc.gov/PressRoom/PressReleases/pr7380-16.

100 In the Matter of Coinflip, Inc., d/b/a Derivabit, and ) Francisco Riordan and the CFTC (17 Sep 2015) at https://www.cftc.gov/sites/default/files/idc/groups/public/@Irenforcementactions/documents/legalpleading/ enfcoinfliprorder09172015.pdf.

${ }^{101}$ Baker and McKenzie, 'A Complete Guide to Cryptocurrencies and ICOs in Thailand' at https://www.bakermckenzie.com//media/files/insight/publications/2018/09/bk_thailand_completeguidecryptoicos_sep18.pdf?la=en. 102 Action Plan for Business Growth and Transformation Act (passed on 11 April 2019), summary found at https://www.amf-france.org/en_US/Reglementation/Dossiers-thematiques/Fintech/Vers-un-nouveau-regimepour-les-crypto-actifs-en-France.
} 
On the other hand, China has banned crypto-asset commercial activity i.e. purchasing, trading, intermediating crypto-asset investments, and payment and exchange services relating to cryptoassets. The Chinese ban ${ }^{103}$ has been attributed to policy-makers' concerns that Chinese capital would be transferred via crypto transactions to overseas markets and evade capital controls. ${ }^{104}$ Further, this ban is also in line with China's crackdown on shadow banking in general, where financial activity has been shifting away from mainstream regulated institutions that are perceived to be too restrictive or expensive. ${ }^{105}$ South Korea has also banned initial coin offerings and token sales, ${ }^{106}$ but given its existing large markets in cryptocurrency trading, it does not ban crypto-currency trading except that such trading cannot be anonymous. ${ }^{107}$ Jurisdictions that take such approaches have unique domestic concerns and do not necessarily contribute to international regulatory leadership.

The European financial regulatory agencies, the European Banking Authority ${ }^{108}$ and European Securities and Markets Authority ${ }^{109}$ have so far focused on financial aspects such as consumer protection and regulatory arbitrage. The position taken is that existing regulatory regimes are upheld as adequate as they are 'technologically-neutral' and regulators take an approach of assessing functional equivalence to see if tokens sold by DLT-based business models fall within existing regulatory regimes. The focus is on combatting regulatory arbitrage rather than looking at regulatory reform. Indeed Maijoor's speech ${ }^{110}$ indicates an aversion to design regulatory reform that chases after particular new technologies. The coherentist approach ${ }^{111}$ is followed in regulators' response to developments in the crypto-economy, such as the extension of anti-money laundering regulation ${ }^{112}$ to crypto-currency businesses, so that channels for money laundering would not be facilitated.

We argue that skewed effects can result from an imbalanced over-emphasis on designing regulatory policy for the financialised aspects of the crypto-economy. If token sales are regarded as falling within the regulatory perimeter for securities regulation, regulators would be presuming that the DLT-based business model is a corporate form. Should such a presumption be made? The corporate form may indeed be unsuitable for the DLT-based business models as concepts of shareholder primacy or directorial control may need adjustment in the face of stakeholder importance and involvement in such economies. ${ }^{113}$ If token sales are not regarded the same as securities offerings,

103 'China Officially Bans All Crypto-Related Commercial Activities' (Aug 2018) at https://bitcoinist.com/chinaofficially-bans-crypto-activities/.

104 'China Bans All Crypto Events After Spending \$3 Billion to Fund Blockchain Startups' (22 Aug 2018) at https://www.newsbtc.com/2018/08/22/china-bans-all-crypto-events-after-spending-3-billion-to-fundblockchain-startups/.

${ }^{105}$ See Wei Shen, Shadow Banking in China: Risk, Regulation and Policy (Cheltenham: Edward Elgar 2016) at chs 5-9.

106 'Why South Korea had to ban crypto-ICOs' (2 March 2019) at https://www.ccn.com/why-south-korea-bancrypto-ico-risk-billion-dollars.

107 'South Korea to ban cryptocurrency traders from using anonymous bank accounts' (23 Jan 2018) at https://www.reuters.com/article/us-southkorea-bitcoin/south-korea-to-ban-cryptocurrency-traders-fromusing-anonymous-bank-accounts-idUSKBN1FC069.

108 EBA (2018) above.

${ }^{109}$ Steven Maijoor speech, 'Cryptoassets: Time to Deliver' (26 Feb 2019).

110 Ibid.

111 Brownsword (2019).

112 Directive (EU) 2018/843 of the European Parliament and of the Council of 30 May 2018 amending Directive (EU) 2015/849 on the prevention of the use of the financial system for the purposes of money laundering or terrorist financing, and amending Directives 2009/138/EC and 2013/36/EU, Arts 2(1)(g), 3(18) and Preamble paragraphs 8-10.

${ }^{113}$ See Bronwen Morgan and Declan Kuch, 'Radical Transactionalism: Legal Consciousness, Diverse Economies, and the Sharing Economy' (2015) 42 Journal of Law and Society 556. 
the disapplication of securities regulation paves the way for opportunities to rethink economic and regulatory models. Further, commentators may characterise crypto-tokens as futures contracts within a financialised paradigm ${ }^{114}$ but can tokens be regarded as commercial sales instead? Such treatment would pave the way for thinking about potential reforms in sales laws to cater for the productive aspects of DLT-based business models, and entail the development of new commercial rights and obligations.

Regulatory policy focused on financial regulation can also encourage the crypto-economy to become more and excessively financialised, attracting more financiers than productive economic agents to the sphere. Token secondary markets are already highly speculative and volatile, ${ }^{115}$ and this space has become increasingly populated by actors in conventional financial economies, such as institutions, sophisticated and high net worth investors ${ }^{116}$ who constantly seek yield and diversification of their portfolios in new asset classes. ${ }^{117}$ Policy-makers focus on deterring retail participation ${ }^{118}$ in the 'wild west' crypto-markets, reinforcing the crowding-out of their participation. Indeed a narrow focus on meeting the goals of financial regulation, such as attacking regulatory arbitrage, defending the existing regulatory perimeter and consumer protection by deterring entry, would likely result in an excessive financialisation of the crypto-economy, turning it into a market for lemons and high speculation, deterring economic agents who are interested in its productive capacities. Financial innovations such as crypto-derivatives or crypto-funds may also contribute towards excessive speculative and financial participation in the crypto-economy, ${ }^{119}$ eclipsing the attractiveness and development of real productivities. ${ }^{120}$

The development of Facebook's digital currency Libra may galvanise internationally concerted response focused on financial regulation. As Facebook has 2 billion existing users, Libra has the potential to become a private money transfer network beyond any national regulation. This has sparked fears of facilitation of money laundering and fraud. ${ }^{121}$ Riding on the international consensus

${ }^{114}$ Hui Deng, Robin Hui Huang and Qingran Wu, 'The Regulation of Initial Coin Offerings in China: Problems, Prognoses and Prospects' (2018) 19 EBOR 465.

115 Thomas Bourveau, Emmanuel T De George, Atif Ellahie and Daniele Macchiocchi, 'Initial Coin Offerings:

Early Evidence on the Role of Disclosure in the Unregulated Crypto Market' (2018) at

https://ssrn.com/abstract=3193392.

${ }^{116}$ Sophisticated investors and their financial intermediaries are usually exempted from a wide range of retail customer duties and protection, under the Markets in Financial Instruments Directive Art 24.

117 The appetite of institutional investors to diversify into cryptos, which some already regard as an asset class, see Lin Lin and Dominika Nestacorva, 'Venture Capital in the Rise of Crypto Economy: Problems and Prospects' (2019) 16 Berkeley Business Law Journal forthcoming and 'What We Learnt from 100 Crypto-talks with Institutional Investors' (2019) at https://www.coindesk.com/what-we-learned-in-100-crypto-asset-talks-withinstitutional-investors.

118 FCA, Consumer Attitudes and Awareness of Cryptoassets: Research Summary (March 2019) at https://www.fca.org.uk/publications/research/consumer-attitudes-and-awareness-cryptoassets-researchsummary.

${ }^{119}$ Speculative and risky finance is a Minskian trajectory, see Hyman Minsky, 'The Financial Instability Hypothesis' (Levy Institute Working Paper 1992) at http://www.levyinstitute.org/pubs/wp74.pdf, also Emilios Avgouleas, 'Regulating Financial Innovation: A Multifaceted Challenge to Financial Stability, Consumer Protection, and Growth' in Niamh Moloney, Eilis Ferran and Jennifer Payne (eds), Oxford Handbook of Financial Regulation (Oxford University Press, 2015).

${ }^{120}$ A general warning sounded in Marianna Mazzucato and Carlotta Perez, 'Innovation as Growth Policy: The Challenge for Europe' (2014) at https://papers.ssrn.com/sol3/papers.cfm?abstract_id=2742164.

${ }^{121}$ Warnings by Fed Chair Powell at https://www.forbes.com/sites/billybambrough/2019/07/11/blow-tobitcoin-as-fed-chair-jerome-powell-issues-stark-facebook-warning/\#1977c23f3eaf; US Treasury chief and the BOE Governor at https://www.bbc.com/news/business-48998304 and https://www.theguardian.com/business/2019/jul/02/facebook-warned-libra-cryptocurrency-will-come-under- 
on subjecting cryptocurrency to anti-money laundering, we may see quickened international policymaking led by central banks and financial regulators, steering policy-making firmly into the realm of money and financial regulation. We advocate against relying on the EU financial regulators to dominate policy-making for the crypto-economy and discuss the contesting forces below that affect the locus of policy-making. We argue that a systemic and holistic approach, as discussed in Section IV, is preferred.

\section{b. The European System of Financial Supervision and Role in Regulating the Crypto-economy}

The European System of Financial Supervision (ESFS) was first created in 2010, ${ }^{122}$ comprising of three agencies, the EBA, ESMA and European Insurance and Occupational Pensions Authority (EIOPA), a Joint Committee of the three authorities and the European Systemic Risk Board (ESRB), a dedicated outfit to monitoring systemic risk which is situated under the umbrella of the European Central Bank (ECB). The EBA, ESMA and EIOPA have been created in the aftermath of the global financial crisis, purposed towards preserving the stability and well-functioning of EU financial markets, while not compromising the integration of the internal market. ${ }^{123}$ They oversee national regulators and are chiefly responsible for technocratic policy-making and ensuring regulatory convergence. The three agencies and the Joint Committee have become a technocratic governance system for EU financial regulation. Further, ESMA in particular has become increasingly empowered to assume direct regulatory competencies. This started with oversight of credit rating agencies ${ }^{124}$ and trade repositories, ${ }^{125}$ seen as pan-European operations. In light of the British withdrawal from the EU, there are further plans to increase the remit of ESMA's pan-European direct authorisation and supervision of regulated entities, bringing an even more centralised approach to EU securities and markets regulation, such as over pan-European collective investment funds of various types, central counterparties. ${ }^{126}$

The architecture of the ESFS is poised to be the 'natural home' for policy development for the crypto-economy. Indeed, there are market failures galore in the crypto-economy that could easily warrant policy intervention, such as dealing with scams, poor market conduct on unregulated markets and the risks posed to investors by custodial services providers. ${ }^{127}$ However, the regulatory agencies have not taken the step of extending the existing regulatory perimeter to crypto-equivalent activities. A key action taken is the issuance of warnings for consumers against participation in the crypto-economy. ${ }^{128}$ Regulators may be wary of prematurely legitimising the crypto-economy for the $\mathrm{EU}$ as a whole. Nevertheless, regulatory hesitation does not stop new activities from constantly

close-scrutiny. The ECB's warning is at https://www.bloomberg.com/news/articles/2019-07-07/facebook-scryptocurrency-plan-draws-ecb-warning-on-regulation.

${ }^{122}$ See the EBA, ESMA, EIOPA and ESRB Regulations, infra.

123 Jacques de Larosière and others, Report by the High Level Group on Financial Supervision in the EU (Brussels, 25 February 2009) http://ec.europa.eu/internal market/finances/docs/de larosiere report en.pdf.

${ }^{124}$ Regulation (EC) No 1060/2009 of the European Parliament and of the Council of 16 September 2009 on credit rating agencies amended in 2011, 2013.

${ }^{125}$ Regulation (EU) No 648/2012 of the European Parliament and of the Council of 4 July 2012 on OTC derivatives, central counterparties and trade repositories.

${ }^{126}$ Danny Busch, 'A Stronger Role for the European Supervisory Authorities in the EU27' in Danny Busch, Emilios Avgouleas and Guido Ferranini (eds), The Capital Markets Union in Europe (Oxford: OUP 2019) at ch3. 127 Section II.

${ }^{128}$ FCA, 'Consumer warning about the risks of investing in cryptocurrency CFDs' (Nov 2017) at https://www.fca.org.uk/news/news-stories/consumer-warning-about-risks-investing-cryptocurrency-cfds; FCA, 'Cryptoassets' (7 March 2019) at https://www.fca.org.uk/consumers/cryptoassets; 'ESAs warn consumers of risks in buying virtual currencies' (12 Feb 2018) at https://eba.europa.eu/-/esas-warn-consumers-of-risks-inbuying-virtual-currencies. 
arising. Warning and deterring the perceived 'vulnerable' consumer does not help in preparing them ${ }^{129}$ for new developments and a new economic future. Further, financial regulators' focus on consumer protection would have the unfortunate effect of exacerbating the financialisation of the crypto-economy and undermining its productive development.

Although the EU regulatory agencies are poised to take technocratic leadership over the policy and regulatory development for the crypto-economy, no significant move is made. However, the agencies' refrain also does not kickstart a broader movement for holistic policy consideration. We predict that the financial regulatory agencies are likely to continue to 'wait and see' and this position can be supported by the following reasons. First, the agencies rightly see themselves as influencing but ultimately implementing the policies that are approved at the institutional level ie in the Commission's communications and policies embodied in law. Second, the agencies are exceedingly mindful of the prematurity of 'throwing their weight' behind the crypto-economy while sensemaking is underway. Third, the agencies actually perceive a larger picture of the crypto-economy than its financialised aspects and are urging policy-making institutions in the EU to address this. However the third is only tentatively discerned.

First, the financial regulatory agencies are responsible for market integration, consumer protection and systemic stability monitoring. ${ }^{130}$ Market integration policies emanate from the European Commission, and the Commission has indicated a preference to wait for international developments, possibly from the Financial Stability Board, before formulating any proposal for crypto-assets. ${ }^{131}$ The agencies' role at the moment may be that of information learning and synthesis, as they are tasked to systemically consider fintech in all aspects of their work, and to monitor national regulators' development of regulatory sandboxes. ${ }^{132}$

However, it can be argued that the agencies are deliberately slow to put policy reform suggestions forward not because they cannot but because they chose not to do so. The agencies are regarded as technocratic experts and there is no preventing them from giving their views as to what regulatory policy should be instituted, such as in relation to the major move to overhaul prudential regulation for investment firms. ${ }^{133}$ This refrain from articulating definite policy for the crypto-economy is a form of self-restraint that is not explained by limitations of remit alone. Maijoor's speech ${ }^{134}$ indicates an unwillingness to prematurely recognise the legitimacy of activity in the crypto-economy at the EU level. This may be because the borderless nature of crypto-economic activities may find a natural fit in the Single Market and policy-makers remain unsure if they wish to build a single market in this new economy. Further, Maijoor's speech also indicates a preference for technology-neutral laws and

\footnotetext{
${ }^{129}$ For example the FCA conducted research to show that few consumers understand cryptocurrencies or assets and not many participate in these markets, but such a survey need not be 'educational' for consumers, see FCA, Consumer Attitudes and Awareness of Cryptoassets: Research Summary (March 2019) at https://www.fca.org.uk/publications/research/consumer-attitudes-and-awareness-cryptoassets-researchsummary.

${ }^{130}$ These are their legislative remits under their respective founding Regulations.

${ }^{131}$ EU Commission Communication, FinTech Action Plan (2018).

132 above.

133 EBA, Advice on New Prudential Framework for Investment Firms (Sep 2017) at https://eba.europa.eu/-/ebaissues-opinion-on-the-design-of-a-new-prudential-framework-for-investment-firms which has now been introduced into legislation, see Parliament's press release in April 2019, at http://europa.eu/rapid/pressrelease IP-19-2130 en.htm?locale=en.

${ }^{134}$ Steven Maijoor speech, 'Cryptoassets: Time to Deliver' (26 Feb 2019).
} 
regulations to be developed, ${ }^{135}$ so that they can be well-considered and produced for timeless objectives.

It is arguably a myth that financial regulation is mostly technologically-neutral. Although there is an endeavour to grapple with the functional substance of financial products and type of intermediary service in regulating them, ${ }^{136}$ there has been a need to specify regulatory expectations of conduct in relation to particular types of technology simply because these give rise to specific issues and risks. For example, the Markets in Financial Instruments Directive's imposition of governance, oversight and responsibilities for algorithmic high-frequency traders shows that specific governance needs were perceived and a functional regulation of market participants' duties that applied more broadly did not suffice. ${ }^{137}$ It may however be argued that market participants' conduct are largely regulated by market rules and hence regulatory intervention only seeks to provide the public goods where market rules have not. However, the example of the Payment Services Directive 2015 is also raised where non-bank providers in the payment services markets that deal with effecting payments and aggregating account information services are given recognition and a regulatory framework for them has been introduced in order to further competition in payment services markets. ${ }^{138}$ Such regulatory policy is developed in order to promote non-bank data-based business models that are able to provide new payment and account management interfaces. It is a response to technological developments. The Commission's Fintech Action Plan that exhorts use of remote know-yourcustomer diligence processes and electronic identifications is also a policy that responds to technological developments and signifies acceptance and endorsement. ${ }^{139}$ Hence, the refrain from taking a position on the crypto-economy in terms of its new technology of disintermediated business models and token financing cannot really be attributed to the need for technologically-neutral regulation. Rather, there is still a lack of sense-making in relation to the crypto-economy, hence tentativeness in endorsing or rejecting the technology that underlies and powers the cryptoeconomy.

The financial regulatory agencies' refrain from taking steps in financial regulation paves the way for a more systemically-driven approach, which the article argues is the right one. However, there still needs to be a push towards that trajectory, or the refrain on agencies' part would merely leave a gap for collective action inertia. Cortez warns that a 'wait-and-see' attitude with respect to regulating innovative developments may entail regulatory policy that is too inert and late in catching up with governance needs. ${ }^{140}$ We observe that the EBA explicitly warns that policy-making on cryptoassets is not complete without a consideration of broader issues in relation to the crypto-economy that is

\footnotetext{
135 Ibid.

136 This means that the regulatory perimeter was no longer determined according to the label of the institution concerned, such as being a bank, insurance or securities firm, but extended to any institution that is carrying out any of the activities of a functionally equivalent nature. See UK Financial Services Authority's exemplification of this approach, FSA v Anderson \& Ors (2010) EWHC 599 Ch.

${ }^{137}$ Art 17, Markets in Financial Instruments Directive 2014.

${ }^{138}$ Directive (EU) 2015/2366 of the European Parliament and of the Council of 25 November 2015 on payment services in the internal market, amending Directives 2002/65/EC, 2009/110/EC and 2013/36/EU and Regulation (EU) No 1093/2010, and repealing Directive 2007/64/EC, Arts 46-48, 64-66 on payment initiation service providers' duties and responsibilities, Arts 33, 69, 97 for account information service providers, for example.

${ }^{139}$ EU Commission Communication, FinTech Action Plan (2018).

${ }^{140}$ Nathan Cortez, 'Regulating Disruptive Innovation' (2014) 29 Berkeley Technology Law Journal 175.
} 
beyond financial sector regulators' remit. ${ }^{141}$ However, we tease out the challenges for developing an EU regulatory policy for the crypto-economy a systemic level.

\section{Systemically-driven Forces for Shaping Policy and Regulation}

There are several factors that would drive a systemic approach to thinking about policy and regulation for the crypto-economy in the EU. First, if the crypto-economy is adopted as part of the Single Market project, whether as part of the Capital Markets Union ${ }^{142}$ or more broadly, then systemic policy thinking can be developed by the Commission. We will however discuss ideological and political pushbacks against this development. Second, if the financialisation of the cryptoeconomy results in significant financial activity and threats to the systemic stability of the EU financial markets, then there would also likely be concerted action to address such developments, as we have seen how the global financial crisis prompted institutional-level reforms resulting in the ESFS $^{143}$ as well as a range of regulatory reforms cutting across many areas. ${ }^{144}$ However such developments would not put European governance in good light as policy leadership would be seen as lacking until too late. Finally, a systemic approach to policy and regulation for the crypto-economy can arise out of applying an innovation policy framework. Although EU innovation policy continues to be somewhat fragmented, Section IV offer suggestions on how it can offer a unifying and integrated approach to policy and regulation.

First, would the crypto-economy be adopted as part of the Single Market project? It is arguable that the crypto-economy, being borderless, is rather compatible with the promotion of cross-border economic participation in the Single Market. Further, the crypto-economy features mainly businesses in development or small or medium sized enterprises, and the EU has been particularly sympathetic to their developmental financing needs. ${ }^{145}$ However, the adoption of an agenda for the single market in the crypto-economy is likely to be resisted by both the demand and supply sides, i.e. the crypto-economy developers and the EU policy-makers alike.

On the demand side, crypto-economy developers arguably look to being borderless globally and may not wish to limit themselves to the Single Market. It is already observed that many DLT-based business models are incorporated offshore ${ }^{146}$ and offer their tokens worldwide. They may have little need of the European passport for access to markets, although the conferment of legitimacy may hugely boost their prospects. Further, the Single Market is regarded as an ordoliberal project, ${ }^{147}$ i.e. the building up of an economic order of free markets and based on liberal philosophy, but underpinned by an overall public order and institutional governance framework. This philosophical underpinning of the Single Market may be regarded as incompatible with the crypto-economy which

${ }^{141}$ European Banking Authority, Report with Advice for the European Commission on Crypto-assets (Jan 2019) at https://eba.europa.eu/documents/10180/2545547/EBA+Report+on+crypto+assets.pdf.

${ }^{142}$ See https://ec.europa.eu/info/business-economy-euro/growth-and-investment/capital-markets-union en for the 2015 initiative and the regulatory output delivered pursuant to this initiative.

${ }^{143}$ Discussed earlier, also see Paul Weismann, European Agencies and Risk Governance in EU Financial Market Law (Oxford: Routledge 2016).

${ }^{144}$ See Mads Andenas and Iris H-Y Chiu, The Foundations and Future of Financial Regulation (Oxford: Routledge 2014).

${ }^{145}$ See https://ec.europa.eu/info/business-economy-euro/growth-and-investment/capital-marketsunion/capital-markets-union-action-plan/financing-innovation-start-ups-and-non-listed-companies en which comprises the Capital Markets Union initiatives to address small business financing such as by dedicated investment fund structures and the regulation of online crowdfunding platforms.

${ }^{146}$ Such as the Cayman islands, British Virgin Islands.

${ }^{147}$ Christian Joerges, 'The European Economic Constitution and its Transformation through the Financial Crisis' (2015) at https://papers.ssrn.com/sol3/papers.cfm?abstract_id=2560245. 
is highly decentralised and according to some commentators, represents an anarcho-capitalist order defying conventional authority and institutional structures. ${ }^{148}$ Even if crypto-economy developers do not necessarily take such an anti-establishment stance, the ethos of the crypto-economy is bottomup in nature and appeals to a new form of democracy and participation. ${ }^{149}$ Hence there may be wariness against the economic governance policies and institutions of the EU. There is significant literature critiquing European economic governance as being too strait-jacketing and liable to produce injustice, ${ }^{150}$ being too dogmatic in relation to its preference for technocratic stewardship of economic and market policies and thus becoming socially disembedded ${ }^{151}$ and politically unaccountable. ${ }^{152}$ More recently, European economic governance has been criticised to be unsustainably centralise ${ }^{153}$ and unable to coordinate with necessary divergences and diversity of needs at more local levels. ${ }^{154}$

On the supply side, policy-makers may not be keen to include the crypto-economy in the Single Market project as the actors in the crypto-economy are institutionally unfamiliar ${ }^{155}$ and there is therefore an absence of political trust to bring the crypto-economy developers within the fold of the Single Market project. Crypto-economy developers first developed alternative currency to represent and transfer value, challenging sovereign-backed currencies, thus pitting themselves as challengers to existing institutions. Policy-makers have repeatedly disavowed the characteristics of cryptocurrencies as sufficient for becoming 'money'. ${ }^{156}$ Token issuers however continue to embrace the 'alternative' ethos of creating and representing value in private terms via the ledger's native token. ${ }^{157}$ As different tokens populate the crypto-economy, it may be increasingly difficult for tokens to gain such network effects as to really disrupt conventional instruments of money and investment. Policy-makers may wish to leave this unregulated space alone as it could be strategic to allow the competition of tokens to result in their own demise, rather than to confer legitimacy and lend traction to their disruptive designs. Regulatory policy has thus far focused on existing familiar

\footnotetext{
148 John Flood and Lachlan Robb, 'Trust, Anarcho-Capitalism, Blockchain and Initial Coin Offerings' (2017) at http://ssrn.com/abstract=3074263.

149 Gavin Wood, Aeron Buchanan, 'Advancing Egalitarianism' in The Handbook of Digital Currencies (Elseiver 2015) at ch19.

150 Mainly in relation to how the single currency entailed implications for fiscal discipline and the stringency of post-crisis fiscal rules for countries that needed financial rescue, see Fabian Amtenbrink, 'New Economic Governance in the European Union: Another Constitutional Battleground?' in Karl Purnhagen and Peter Rott (eds), Varieties of European Economic Law and Regulation: Liber Amicorum for Hans Micklitz (Heidelberg: Springer 2014) at ch 11; Alexandre de Streel, 'The Evolution of the EU Economic Governance since the Treaty of Maastricht: an Unfinished Task' (2013) 20 Maastrict Journal 3.

151 Daniel Muggë, 'From Pragmatism to Dogmatism: European Union Governance, Policy Paradigms and Financial Meltdown' (2011) 16 New Political Economy 185; Michelle Everson, 'A Technology of Expertise: EU Financial Services Agencies' (LSE Working Papers 2012).

152 Poul F Kjaer, 'European Crises of Legally-Constituted Public Power: From the "Law of Corporatism" To The "Law Of Governance"” (2017) 23 European Law Journal 417.

${ }^{153}$ Wolfgang Munchau, 'The Unsustainable Unbreakable Eurozone' (Financial Times, 28 April 2019) looking at the unsustainability of managing European countries' fiscal crises sustainably for the future.

154 Muggë (2011); Sergio Fabbrini, ‘Beyond Intergovernmentalism: The Puzzle of European Economic Governance' in M. J. Rodrigues and E. Xiarchogiannopoulou (eds.), The Eurozone Crisis and the Transformation of the EU Governance: External And Internal Implications (Aldershot: Ashgate, 2014) at ch4.

155 Howard E. Aldrich, C. Marlene Fiol, 'Fools Rush in? The Institutional Context of Industry Creation' (1994) 19 Academy of Management Review 645-670, discussing how unfamiliarity (in a more social and cognitive sense) entails institutional and political distrust of innovation.

156 Part V, BIS Annual Economic Report 2018, 'Cryptocurrencies- Looking Beyond the Hype' at

https://www.bis.org/publ/arpdf/ar2018e5.pdf.

157 Tokens are offered for cryptocurrency such as bitcoin or ether in return.
} 
industry structures, such as the industry for fund and asset management, ${ }^{158}$ to develop a range of financing products to meet needs such as in infrastructure, ${ }^{159}$ social entrepreneurship ${ }^{160}$ or venturecapital. ${ }^{161}$ These would be offered by conventional investment intermediaries, a sector already regulated and deeply engaged by policy and governance institutions in the EU. ${ }^{162}$

Further, policy-makers may not be keen to develop economic governance for the crypto-economy as harmonisation of rules relating to the productive aspects of conventional economies has already been a chequered path, such as in relation to harmonisation of company laws in the EU. The productive aspects of conventional economies are deeply rooted in different national political economies ${ }^{163}$ where for example, different relations or bargains have been struck between labour and capital, ${ }^{164}$ different industrial policies exist, ${ }^{165}$ and different legal frameworks for economic actors such as creditors, suppliers etc exist. ${ }^{166}$ Hence, it is observed that harmonising EU company law has been tricky and gradual ${ }^{167}$ as fundamental contextual and institutional differences in member states do not justify a one size fits-all approach. Further, even in securities markets regulation where standards of corporate governance ${ }^{168}$ or shareholder stewardship ${ }^{169}$ have gained convergent adoption, there remain differences in detail applicable to different capital markets. ${ }^{170} \mathrm{It}$

\footnotetext{
158 The EU Commission continues to appeal to the asset management industry for example, in relation to developing sustainable finance, see proposals in EU High Level Expert Group on Sustainable Finance (HLEG), Financing a Sustainable European Economy (2018) (HLEG (2018)).

${ }^{159}$ Regulation (EU) 2015/760 of the European Parliament and of the Council of 29 April 2015 on European long-term investment funds.

${ }^{160}$ Regulation (EU) No 346/2013 of the European Parliament and of the Council of 17 April 2013 on European social entrepreneurship funds.

${ }^{161}$ Regulation (EU) No 345/2013 of the European Parliament and of the Council of 17 April 2013 on European venture capital funds.

162 Eric Monnet, Stefano Pagliari and Shahin Vallée, 'Europe between Financial Repression and Regulatory Capture' (Bruegel Working Paper 2014) at http://bruegel.org/wp-

content/uploads/imported/publications/WP 2014 08 .pdf. The dominance of the industry's influence on
} financial sector governance and policy is also discussed in Peter Mooschlechner, Helene Schuberth and Beat Weber (eds), The Political Economy of Financial Market Regulation (Cheltenham: Edward Elgar 2006); Stefano Pagliari, 'Who Governs Finance? The Shifting Public-Private Divide in the Regulation of Derivatives, Rating Agencies and Hedge Funds' (2012) 18 European Law Journal 44.

163 Peer Zumbansen, 'Spaces and Places: A Systems Theory Approach to Regulatory Competition in European Company Law' (2006) 12 European Law Journal 534.

${ }^{164}$ Such as co-determination in Germany, but contrast with the UK where company law is insularly focused on shareholder-management relations, leaving labour to contractual systems. See Peter A Hall and David Soskice, 'An Introduction to Varieties of Capitalism' in Peter A Hall and David Soskice (eds), Varieties of Capitalism: The Institutional Foundations of Comparative Advantage (Oxford: Oxford University Press 2001) at ch1.

${ }^{165}$ For e.g. the French have an industrial policy to support national champions but the UK has engaged in systematic privatisation since the 1980 s.

${ }^{166}$ Different jurisdictions provide different creditor rights vis a vis companies, and recent developments such as the Dutch approach of broking covenants between firms and government in order to ensure that firms do not engage in abuses in their supply chain is different from other jurisdictions, such as the UK's approach that leave supply chain governance to largely contractual governance but subject to skeletal forms of disclosure, s54, Modern Slavery Act 2015.

167 Zumbansen (2006).

168 Mathias Siems, 'Convergence in Corporate Governance: A Leximetric Approach' (2010) 35 Journal of Corporation Law 729; Carsten Gerner-Beuerle, 'Determinants of Corporate Governance Codes' (2014) at http://papers.ssrn.com/sol3/papers.cfm?abstract_id=2346673.

169 Jennifer G Hill, 'Good Activist/Bad Activist: The Rise of International Stewardship Codes' (2018) 41 Seattle University Law Review 497.

${ }^{170}$ Gen Goto, 'The Logic and Limits of Stewardship Codes: The Case of Japan' (2019) Berkeley Business Law Journal, forthcoming. 
may however be argued that institutional baggage would not be an issue for the crypto-economy as charting away from institutional frameworks has been its design, and it may be easier and more efficient to introduce harmonisation thinking for policy and regulation for the crypto-economy.

On whether there may be financial systemic stability threats from the crypto-economy that may compel concerted action on the part of EU policy-makers, the Financial Stability Board has dismissed such threats as the scale of activity is currently small compared to conventional financial economies. ${ }^{171}$ However, as cryptocurrency has always been meant to operate interchangeably with fiat currency, ${ }^{172}$ this fundamental tenet of exchange makes porous the crypto-economy to real and financial economies. Further, Facebook's Libra project may pose threats to financial integrity and stability at scale. Conventional financial actors may become new intermediaries for the cryptoeconomy as they propose to develop financial products in the form of funds, such as exchangetraded funds, ${ }^{173}$ in order to invite the participation of investors, such as venture capital investors who seek exposure to the new crypto-asset class. Although many crypto-asset exchanges do not erect barriers to trading entry as are found in conventional securities and derivatives markets, ${ }^{174}$ investors may be overwhelmed by the landscape of noise and hype or may not be confident in constructing portfolios for themselves. Existing financial intermediaries are moving into this space to intermediate and seek rent, leveraging upon their incumbent status in conventional financial economies to capture the new investment space. ${ }^{175} \mathrm{It}$ remains to be seen if the scale of conventional, particularly institutional participation in the crypto-economy would rise to more significant proportions and attract policy-makers' attention. On the one hand, this may result in financial-sector focused reforms rather than systemic reforms. However, policy-makers after the global financial crisis 2007-9 have become more forward-looking ${ }^{176}$ in order not to be seen as clueless after the fact. Policy development prompted by large-scale concerns such as global stability may galvanise policy and regulatory development at a systemic level.

Finally, we suggest that systemic policy and regulatory development can come from the adoption of a more broad-based innovation policy in relation to the crypto-economy. The lens of innovation provides a different perspective for understanding the crypto-economy, not just as a space for regulatory arbitrage, being anti-establishment or anarcho-capitalist. The focus on innovation frames the question in relation to the economic changes it augurs, ${ }^{177}$ such as the 'fourth industrial revolution', ${ }^{178}$ allowing policy-makers to appreciate disruptive potential ${ }^{179}$ and possible change to

\footnotetext{
${ }^{171}$ Mark Carney, in a letter as Chair of the Financial Stability Board to the G20 Finance ministers and central bankers, 13 March 2018 at http://www.fsb.org/wp-content/uploads/P180318.pdf.

172 Satoshi Nakamoto (2008).

${ }^{173}$ William M Peaster, 'Crypto \& Blockchain Exchange-Traded Funds (ETFs) Launching in Europe' (March 2019) at https://blockonomi.com/crypto-blockchain-etfs-europe/.

${ }^{174}$ I.e by brokers who intermediate exchange, and potential abuses see Neil Gunningham, 'Private Ordering, Self-regulation and Futures Markets: A Comparative Study of Informal Social Control' (1991) 13 Law and Policy 297.

${ }^{175}$ Fidelity the asset manager intends to provide crypto custodial services, see Matthew Leising and Alistair Marsh, 'Fidelity Is Said to Plan March Launch of Bitcoin Custody Service' (Bloomberg Jan 2019) at https://www.bloomberg.com/news/articles/2019-01-29/fidelity-is-said-to-plan-march-launch-of-bitcoincustody-service; JP Morgan creates a digital token for its payment services, see https://www.jpmorgan.com/global/news/digital-coin-payments.

176 Basel Core Principles 2012, at Principle 8.

177 Susana Borràs, 'Analysing the Innovation Policy of the EU' in Susana Borràs, The Innovation Policy of the European Union: From Government to Governance (Cheltenham: Edward Elgar 2003) at ch1, discussing innovation policy as initiated to deal with the rise of the 'knowledge economy' since the early 2000 s. 178 Klaus Schwab, The Fourth Industrial Revolution (Currency 2017).
} 
business and economic models. Perspectives can be formed as to whether such innovation is more incremental, ${ }^{180}$ or indeed seismic, ${ }^{181}$ and the high level implications of such innovation including ethicality, sustainability, social and political debate. ${ }^{182}$ The lens of innovation policy is argued to be ideal for fostering policy and regulatory development at a systemic level that integrates thinking across a broad spectrum of issues and not merely focused on financial governance.

It may be said that the EU has instituted the Blockchain Observatory and Forum to systematically unpack the innovative potential of distributed ledger technology, and this is the beginning of a systemic approach. We do not disagree as the Observatory and Forum explicitly refers to its interest in making policy recommendations to the European Commission. ${ }^{183}$ However, the Observatory and Forum is a relatively small network at the moment, led by one industry participant and four university participants, three of which are in the UK and may be affected by the UK's withdrawal from the EU in due course. There is a need to consider embedding the policy agenda more deeply within the European institutional governance framework for innovation.

\section{Innovation Policy as the Framework for Designing Regulatory Governance}

We argue that innovation policy provides an optimal basis for developing a systemically-driven framework for regulatory policy in the crypto-economy. Such a framework allows us to take stock of, learn and study the aspects of innovation ${ }^{184}$ and their potential for change, and also consider how such change/s should be governed. ${ }^{185}$

The innovative aspects of the crypto-economy cut across industries, sectors and national economies in relation to (a) business models; (b) technological transformation; (c) new economic connectivities; (d) new economic actors and productivities and (e) new economic derivatives.

(a) In relation to business models, as discussed in Section II above, DLT-based business models are highly decentralised business models that can offer unique goods and services most optimally offered over a blockchain. These models mobilise mass participation towards the provision of network or collective goods or services in the model of a sharing economy. ${ }^{186}$

(b) In relation to technological transformation, distributed ledger technology is a breakthrough that brings together network computing and a protocol of validation and verification through cryptographic methods, therefore enabling more and more complex forms of automation in commercial and non-commercial interactions. ${ }^{187}$

\footnotetext{
${ }^{179}$ Iris H-Y Chiu, 'Fintech and Disruptive Business Models in Financial Products, Intermediation and Markets Policy Implications for Financial Regulators' (2016) 21 Journal of Technology Law and Policy 168.

${ }^{180}$ Described as sedimentary innovation, see Cristie Ford, Innovation and the State: Finance, Regulation, and Justice (Cambridge: CUP 2018).

${ }^{181}$ Above.

182 see Henry TC Hu, 'Financial Innovation and Governance Mechanisms: The Evolution of Decoupling and Transparency' (2015) 70 Business Lawyer 347 on the importance of learning in an objective manner the implications of innovation and disseminating for public education; Stevienna de Saille, 'Innovating Innovation Policy: The Emergence of 'Responsible Research and Innovation' (2015) 2 Journal of Responsible Innovation 152.

183 https://www.eublockchainforum.eu/about.

${ }^{184}$ Ewan Sutherland, 'Trends in Regulating the Global Digital Economy' (2018) at https://papers.ssrn.com/sol3/papers.cfm?abstract_id=3216772.

185 Susana Borras and Jakob Edler, 'Introduction' in Susana Borras and Jakob Edler (eds), The Governance of Socio-technical Systems: Explaining Change (Cheltenham: Edward Elgar 2014).

${ }^{186}$ Sundarajan(2016); Alyse Killeen, 'The Confluence of Bitcoin and the Global Sharing Economy' in The Handbook of Digital Currencies (Elseiver 2015) at ch24.

${ }^{187}$ Explained in de Fillippi and Wright (2018).
} 
(c) In relation to forming new connectivities, smart contracting over DLT platforms can change the dynamics of social and economic relations across different geographies. ${ }^{188}$

(d) In relation to new products, services and commodification, DLT-based business models introduce new commodification beyond the sharing economy which has already brought about changes in terms of how products and services are provided. ${ }^{189}$ Uber allows people who own a car to commodify their 'excess capacity' and generate revenue from carrying out taxi services when available to do so, and AirBnB allows people to commodify their spare rooms in order to generate revenue from holiday lodgers. Commodification raises new issues in relation to how socio-economic relations are conceived and whether more calculativeness is encouraged generally. ${ }^{190}$ These implications should be debated upon in systemic policy thinking.

(e) In relation to 'derivative' products such as finance, crypto-tokens provides a new asset class from which hedging and investible assets can be further created. ${ }^{191}$

A systemic approach is appropriate for considering all the developments and implications of the crypto-economy, ${ }^{192}$ in relation to the goals and objectives of EU policy-making, whether for enhancing growth, economic development and performance of EU economies generally, or for protective purposes such as protection from harm and mitigation of risks. ${ }^{193}$ In this sense we echo commentators' exhortation that innovation policy should be led by public policy. Mazzucato et al support a public policy-led innovation framework as successful innovation requires commitment and governance, as well as funding, both publicly and privately sourced, and public policy leadership can mitigate the ills of myopia and short-termism that the private sector is so frequently embroiled in. ${ }^{194}$ Further commentators also support a pro-innovation policy especially in the aftermath of economic crises in order to facilitate productive recovery and rejuvenation, such pro-innovation policy being able to especially counter the challenges of limited fiscal policies. ${ }^{195}$

\section{EU Innovation Policy}

In the early 2000s, Borràs writes of an emerging governance framework for innovation in the EU. ${ }^{196}$ Such a policy has been driven by Europeanisation pursuant to the goals and aims underpinning the

188 One can also use Neil Fligstein's economic sociology analysis to map the network analyses of actors and structures in new markets, see Neil Fligstein and Ryan Calder, 'Architecture of Markets' in Robert Scott and Stephen Kosslyn (eds), Emerging Trends in the Social and Behavioural Sciences (2015) at http://sociology.berkeley.edu/sites/default/files/faculty/fligstein/architecture\%20of\%20markets\%20Calder\%2 OTrends.pdf, and earlier work Neil Fligstein, The Architecture of Markets (NJ: Princeton University Press 2001). ${ }^{189}$ Sundarajan (2016); Devyani Prabhat, “BorrowMyDoggy.Com': Rethinking Peer-to-peer Exchange for Genuine Sharing' (2018) 45 Journal of Law and Society 84.

190 Jamie Palomera, 'Reciprocity, Commodification, and Poverty in the Era of Financialization' (2014) 55 Current Anthropology S105; also the 'corruption' of objects that should not be subject to a market price, as argued by Tsilly Dagan, 'Commodification without Money' (2010) at http://ssrn.com/abstract=1537586; Michael Sandel, What Money Can't Buy- The Moral Limits of Markets (London: Penguin 2013).

191 Lee (2019).

192 Also see OECD, Innovation Policies in the Digital Age (2017) at https://www.oecd-

ilibrary.org/docserver/eadd1094-

en.pdf?expires=1556192035\&id=id\&accname=guest\&checksum=97455A905BE124534E1626E271C575DD.

193 Susana Borràs, 'Analysing the Innovation Policy in the EU' in Borràs (ed 2003) at ch1.

194 Marianna Mazzucato and Carlotta Perez, 'Innovation as Growth Policy: The Challenge for Europe' (2014) at https://papers.ssrn.com/sol3/papers.cfm?abstract_id=2742164.

195 Mats Benner, 'Innovation Policy in Hard Times: Lessons from the Nordic Countries' (2012) 20 European Planning Studies 1455-1468.

196 Ibid, and ch7; also Peter S Biegelbauer and Susana Borràs ,'Introduction' in Peter S Biegelbauer and Susana Borràs (eds), Innovation Policies in Europe and US: The New Agenda (Aldershot: Ashgate 2003). 
Single Market project and to an extent replaces 'national innovation systems' ${ }^{197}$ that seem to be lacking or incoherent in many developed countries, as an OECD survey suggested. Governance of innovation at the EU is nevertheless multi-level and faceted, reflecting the need for reflexive and not top-down governance in this complex polity, ${ }^{198}$ as well as devolving into different specific trajectories in specific issue areas. ${ }^{199}$ However, there are certain integrated tenets teased out by commentators that can usefully form a framework for considering the crypto-economy more holistically. These tenets are:

(a) Leadership in fostering innovation by funding. As the European Commission has a dedicated Research and Innovation division that focuses on fostering and funding innovation, such leadership is invaluable for signalling policy leadership and implementing innovation. ${ }^{200}$

(b) High level goals and aims in which innovation can be nested, such as the EU Horizon 2020 vision. ${ }^{201}$

(c) Institutional structures that can facilitate innovation in environments of certainty and support, such as the fostering of pan-European intellectual property rights and the development of appropriate European standards. ${ }^{202}$

(d) Institutional structures that incorporate balanced considerations between pro-innovation and protection concerns, such as 'responsible innovation' policies, ${ }^{203}$ i.e. bringing considerations of ethicality, sustainability, protection from harm (whether precautionary or ex post), alongside pro-innovation policies. ${ }^{204}$ Recent initiatives such as the General Data Protection Regulation arguably aims to strike such a balance in protecting individuals' privacy and the use and keeping of their personal data vis a vis commercial convenience.

(e) Multi-level dialogic frameworks for learning and coordination amongst various public and private sector actors although such networks can be criticised for being opaque and not sufficiently open to democratic participation. ${ }^{205}$

Developing an EU innovation policy framework allows for leveraging upon centralised institutional structures as well as engaging in networked dialogue, learning and coordination with local and stakeholder levels. ${ }^{206}$ Such a policy framework should also facilitate more inclusive networking with local and stakeholder levels than is currently envisaged under the Blockchain Observatory and Forum. Such a framework is appropriate for governing change, ${ }^{207}$ so that agents for change and their intentionalities (which may not merely be incentive-based) can be mapped, and we can more clearly discern the structures that create opportunities for change and entrepreneurship. Institutional

197 OECD, Governance of Innovation Systems: Vol 2 (2005).

${ }^{198}$ Arthur Benz, 'Combined Modes of Governance in EU Policy-making' in Ingeborg Tömmel and Amy Verdun (eds), Innovative Governance in the European Union (Colorado: Lynne Reiner 2009) at ch3.

199 Borràs (2003).

200 Ibid in 'Introduction'.

201 https://ec.europa.eu/programmes/horizon2020/en.

202 Borràs (2003) at 'Conclusion', ch7.

${ }^{203}$ Stevienna de Saille, 'Innovating Innovation Policy: The Emergence of 'Responsible Research and Innovation' (2015) 2 Journal of Responsible Innovation 152; and legalising an initiative of responsible innovation in the financial sector, see María Teresa Casparri, Javier García Fronti, Martín Ezequiel Masci, 'Responsible Financial Innovation in Banks: Committees of New Products' (2015) 19 Revista Científica "Visión de Futuro" at :<http://www.redalyc.org/articulo.oa?id=357941099006> ISSN 1669-7634.

204 De Saille (2015).

205 Susana Borràs and Jakob Edler, 'The Governance of Change in Socio-technical Systems: Three Pillars for a Conceptual Framework' in Borràs and Edler (eds 2014).

${ }^{206}$ Stefan Kuhlmann, 'Future Governance of Innovation Policy in Europe-Three Scenarios' (2001) 30 Research Policy 953.

207 Borràs and Edler (eds 2014). 
factors can then be mapped in relation to how they facilitate or impede change, while broadly considering the levels of democratic participation in shaping policy.

A governance framework for innovation and change at the EU level provides a systemic approach to derive policy and regulation, and will likely facilitate a more holistic and long-termist response to the developments in the crypto-economy.

\section{Conclusion}

This article argues that the EU should consider policy and regulation for the crypto-economy in a systemic and holistic manner, and its institutions and governance frameworks lend themselves to policy-making in that manner. This article argues that the systemic approach to developing policy and regulation is important as the crypto-economy gives rise to new productive aspects that should be carefully considered in relation to economic development, mobilisation and the single market project. Although much global attention is given to the financialised aspects of the crypto-economy and regulatory pioneers seem focused on developing financial and securities regulatory policies, such an approach is narrow in nature and may indeed reinforce the adverse effects of excessive financialisation in the crypto-economy. This article proposes that the EU should develop a framework for innovation and governing change to consider the developments in the cryptoeconomy, so that policy and regulation can be developed in a holistic manner and perhaps feed into the Single Market project. 